\begin{tabular}{|c|c|}
\hline & $\begin{array}{l}\text { International Journal of Trend in Scientific } \\
\text { Research and Development (IJTSRD) }\end{array}$ \\
\hline 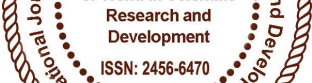 & International Open Access Journal \\
\hline 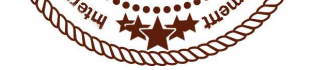 & ISSN No: 2456 - 6470 | www.ijtsrd.com | Volume - 2 | Issue - 2 \\
\hline
\end{tabular}

\title{
Impact of Product Packaging Cues on Product Quality Perceptions: Empirical Evidence from Pakistani Shopping Malls
}

\author{
Anam Javeed, Dr. Sany Sanuri bin Mohd Mokhatr, Dr. Ismail bin Lebai Othman \\ Universiti Utara Malaysia, School of Business Management-Kedah, Malaysia
}

\section{ABSTRACT}

This paper develops and tests a theoretical model of the effects of nutritional label and brand name on consumers' product quality perceptions in Pakistani consumer market. The basic aim of the study is to investigate the extent to which consumers form quality perceptions from product packaging cues. The survey method was employed to collect data from 487 Pakistani consumers in Islamabad and Rawalpindi region using mall intercept method. Five-point Likert scale is used to measure all the dimensions of variables. Descriptive and regression analyses are performed using SPSS and PLS. Cronbach alpha measure is used for all the variables to ensure internal consistency. The finding indicates that brand name as well as nutritional label exerted significant influence on product quality perceptions. Investigating the impact of nutritional label and brand name in Pakistani consumer market is a contemporary and worthwhile topic that shall have noteworthy contribution in prevailing literature as well as to the marketers.

Keywords: Product Quality Perception; Nutritional label; Brand Name; Product Packaging Cues.

\section{INTRODUCTION}

It is frequently assumed that the provision of cues on the product packages leads to the perception development regarding the quality of the product. The evidence of has been provided by Teisl et al. (2001) that the consumers' quality perceptions are being altered by taking packaging cues into consideration. The visual and verbal elements present on the food

package are termed as the cues which give a preconception to buyer at the point of sale regarding the quality. Moreover, in the topical arena of food marketing, the packaged food producers are displaying nutritional labels in addition to other labels like brand name and price tag (Onozoka et al., 2014). Further it is argued by Muth et al. (2013) that the nutritional label allows the consumer to assess the quality of the product. On the similar foundations Trifts et al. (2013) along with Chandon \& Wansink (2007) suggested that the nutritional content labels present evidence regarding the quality of enclosed product prior to the actual usage of the product. The ambiguity regarding the quality of the product persuades the consumers to make use of nutritional label for making inference. As the food packaging labels are associated with the sense of quality of the product, the nutritional label could be one of the quality cues influencing the quality perceptions. In the modern age, consumers like to make informed decisions. Wijngaart (2002) argue that nutritional label is a valued tool to help the consumers in making informed choices. Grunert and Wills (2007) highlight the importance of nutritional labelling by claiming them to be effective and efficient mode of marketing. Teisl and Levy (1997) argue that nutritional labels not only provide quality information but allow the consumers to switch to healthier options of food instead of unhealthy foods.

Brand name is effective in creating product quality perceptions and it establishes the intentions of buyers towards the products. It is also a key element for the 
long term success of relationships (Sharma \& Garg, 2016). With the brand name, buyers generally have to spend very less time to perceive the quality of the product (Randhawa et al., 2017). The stout relationship between brand name and product quality perceptions motivates the frequent buying behavior (Mishra et al., 2017). It has been argued by (Lewis et al., 2016) that relation between the brand name and product quality perception is vital as well complex issue and it should be probed closely in various markets.

\section{LITERATURE REVIEW}

\section{A. Nutritional Label and Perceived Product Quality}

The nutritional labels on the food packages are utilized by the consumers as an extrinsic cue to assess the quality of the product (Fenko et al., 2016). According to signaling theory the cues and stimuli present in the shopping environment are responsible for the perceptions of the consumers (Talati et al., 2016). Particularly, certain empirical studies have found a connection between the nutritional labels and perceived product quality (Darkawa 2014; Rundh, 2013; Walters \& Long 2012). Other studies have proved that nutritional labels cast a positive impact on the perceived product quality (Grunert et al., 2016; Bialkova et al., 2016). Specifically, the studies have verified that the food labels on the food packages in European market have verified that perceived food quality is impacted by the nutritional labels (Verhoef et al., 2016; Oliveria et al., 2016).

\section{B. Brand Name and Perceived Product Quality}

The brand name assists the consumers to recognize the product with much ease; hence it works as memory cue allowing the consumer to recollect the information regarding the product (Winkielman et al., 2000). The brand is responsible for the formation of quality perceptions about the product of the certain brand and these perceptions play a crucial role in final decision making of the consumer (Winkielman et al., 2000). The brand has been studied a major marketing tool b various researchers. According to Chadwick \& Holt (2015) brand gives consumer an additional value and prestige and marketers use it as a tool for gaining competitive advantage. By looking at scenario of Pakistani consumer behaviour regarding the brand preferences, the food brands are considered to be higher in quality then loose food items (Akhtar et al.,
2016). According to Verhoef et al. (2002), the greater the difference between the perceived quality of branded food items and loose food items, the higher would be the preference of consumer to buy branded food. Due to increasing literacy level of females, more contribution of females in workforce and rapid urbanization, the purchasing power is gradually increasing (Lee et al., 2011). The gradual increase in the purchase power is enhancing the consumption of branded packaged products is increasing in Pakistan (Khan \& Nasr, 2010). Although, there is an increasing trend of branded packaged products, but there is a lack of comprehensive study in Pakistani consumer market (Zeb et al., 2011). Additionally, the need of investigating the impact of brand name on food package relative to the other food packaging cues has been stressed upon (Grewal et al., 2015).

\section{THEORETICAL FRAMEWORK}

The present study focus is on the impact of nutritional label and Halal logo as signals from the consumer point of view of product quality perception as these food packaging cues have been referred to be used as frequently by the consumers (Chaya et al., 2016; Bailey., 2017). Previous researches stressed that packaging cues have an impact on consumers' choice. As a matter of fact, packaging cues are suggested to have great impact as a means of direct communication (Peters and Badrie, 2005). A package is acknowledged as a marketing communication tool as packages convey meanings directly to consumers when the decision to purchase is being made. As such, it is commonly accepted that packaging cues convey meanings about the product and its quality (Garber et al., 2000; Rothschild, 1987). Even though the fact that packages convey meanings is well acknowledged, it seems that there are few scholarly studies focusing on food packaging as a means of communicating the unobserved quality (Underwood, 2001; Garber, 1995).

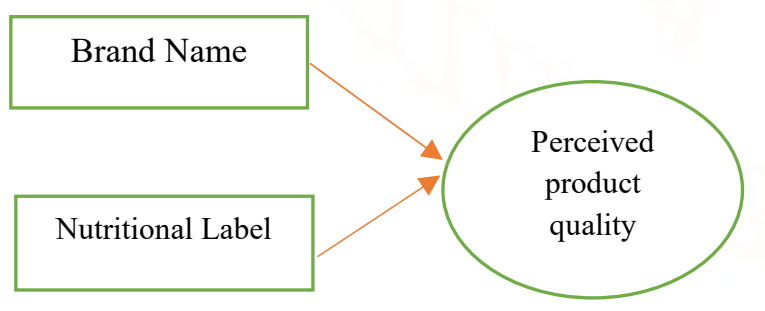

The present study focus is on the impact of nutritional label and brand name as signals from the consumer point of view of product quality perception as these food packaging cues have been referred to be used as 
frequently by the consumers (Oijen et al., 2016; Chaya et al., 2016; Bailey et al., 2016). Previous research stresses that packaging cues have an impact on consumers' choice. As a matter of fact, packaging cues are suggested to have great impact as a means of direct communication (Peters, 1994). A package is acknowledged as a marketing communication tool as packages convey meanings directly to consumers when the decision to purchase is being made. As such, it is commonly accepted that packaging cues convey meanings about the product and its quality (Garber $e t$ al., 2000; Rothschild, 1987). Even though the fact that packages convey meanings is well acknowledged, it seems that there are few scholarly studies focusing on food packaging as a means of communicating the unobserved quality (Underwood, 2001; Garber, 1995; Gordon et al., 1994). Based on the proposed theoretical framework, following hypotheses are drawn which will be put to further analyses

$\mathrm{H}_{1}$ : Brand Name casts a significant impact on product quality perception.

$\mathrm{H}_{2}$ : Nutritional label casts a significant impact on product perceived quality.

\section{METHODOLOGY}

Islamabad and Rawalpindi are selected as sample because they are major big cities of Pakistan having a dense and diverse number of people as inhabitants from all over the country. As the capital of Pakistan, Islamabad is the most developed city. It has up to date amenities and infrastructure and enormous number of educational institutes. Islamabad, the capital city of Pakistan is in the federal capital territory of Pakistan. It is the most diverse and metropolitan city of the country. Being the capital of Pakistan Islamabad comprises of all the head offices of the major companies of Pakistan, has around 16 public and government universities and a wide range of employment opportunities. The estimated population of Islamabad in 2016 was 1433000 (Worldometer, 2016). Despite of its establishment in 1960's Islamabad has settled well and grown in population steadily. Rawalpindi is the neighbor city of Islamabad and termed as twin cities. Together they form Islamabad- Rawalpindi metropolitan area. Rawalpindi has a population of approximately 2.506 million which diverse from all over the country.

\section{A. Data Collection}

After calculating the sample proportions city wise, from the list of shopping malls, major shopping centres were selected from both cities based on the high customer turnout, geographical coverage and popularity. To get the results which will be generalizable and representative, the chosen random sampling technique should be appropriate. The strategy used in this study is collecting data from general consumer using systematic random sampling via mall intercept method. This sampling involves in drawing every nth element in the population starting with random number between 1 and $\mathrm{n}$ (Sekeran, 2003).

Table `1: Shopping centres within city limits

\begin{tabular}{|c|c|c|c|}
\hline$\overline{\text { City }}$ & Mall & Criteria for se & election \\
\hline Islamabad & $\begin{array}{c}\text { Centaurus } \\
\text { Mall }\end{array}$ & \multirow{8}{*}{$\begin{array}{l}\text { Geographical } \\
\text { coverage, } \\
\text { customer } \\
\text { Popularity }\end{array}$} & \multirow{8}{*}{$\begin{array}{l}\text { High } \\
\text { turnout, }\end{array}$} \\
\hline Islamabad & Beverly & & \\
\hline$\square$ & Center & & \\
\hline Islamabad & Kohsar Market & & \\
\hline Rawalpindi & CSD Mall & & \\
\hline Rawalpindi & $\begin{array}{c}\text { CSD Super } \\
\text { Mall }\end{array}$ & & \\
\hline $\begin{array}{l}\text { Rawalpindi } \\
\text { Cand }\end{array}$ & $\begin{array}{c}\text { Green valley } \\
\text { premium } \\
\text { Hyper mart }\end{array}$ & & \\
\hline Rawalpindi & Rafy Mall & & \\
\hline
\end{tabular}

\section{B. Data Analysis Strategy}

Data analysis will be done by using combination of descriptive and inferential analysis. SPSS has been used to carry out the descriptive analysis to obtain a general understanding as well as for profiling the respondents. SPSS will be used for summarizing the data, making various tabular presentations and for measuring the frequency of occurrence of the outcomes. On the other hand, for making predictions from the data, inferential analysis was conducted using SEM.

\section{Descriptive Analysis}

The descriptive analysis was performed in order to describe the primary features of the data set. The descriptive analysis was performed by looking at every variable and its dimensions. Sekeran and Bougie (2010) state that descriptive analysis is basically explained via mean, standard deviation, 
variance in order to obtain a general view about how the respondents have responded to questionnaire.

Table 2 (APPENDIX) shows the mean and standard deviation values of the data. The mean values of the data range from 3.7436 and 4.103 which are among the acceptable range. The values of standard deviation also lie in tolerable range of 0.5746 and 0.67987 .

\section{Reliability Test}

The values of factor loading demonstrate the strength of each item on its respective construct. According to Fornell \& Larker (1981) suggestion, the items with loading higher than 0.50 or more is acceptable for multivariate analysis. (APPENDIX)

\section{E. SEM Path Analysis}

This study implants structural equation modelling (SEM) for hypothesis testing. Two most popular approaches in SEM are covariance based approach and variance based approach. AMOS, LISERAL use covariance based approach however variance based approach is being used by partial least squares. Covariance based CBSEM is confirmatory in nature however variance based VBSEM is prediction oriented. Models with complex nature and numerous latent and manifest variables can be estimated easily. According to Chin et al. (2003) SEM is capable of running hierarchical models, or moderating and mediating effects. Vinzi et al. (2010) states causal relationship of the model is calculated among the latent variables estimated by means of observed indicators named as manifest variables. Table 4 shows the values of path coefficients

Table 4: Path Coefficient

\begin{tabular}{|l|l|l|l|}
\hline & Coefficient & $\begin{array}{l}\text { T- } \\
\text { Statistics }\end{array}$ & P values \\
\hline $\begin{array}{l}\text { Brand Name } \\
>\text { PQ }\end{array}$ & 0.298 & 5.287 & 0.000 \\
\hline $\begin{array}{l}\text { Nutritional } \\
\text { Label }>\text { PQ }\end{array}$ & 0.083 & 1.748 & 0.081 \\
\hline
\end{tabular}

The $\mathrm{T}$ statistics and $\mathrm{P}$ value evidently show that the Brand Name as well as Nutritional label has an evident and significant relationship with perceived quality.

\section{CONCLUSION AND DISCUSSION}

In modern time of food marketing, food packaging cues are playing a vital role in consumer behavior. Food packaging cues enables the consumers to develop the quality perceptions. Questionnaire method was adopted to collect the data from the consumers of Islamabad and Rawalpindi. The current study approves that $\mathrm{H} 1$ Brand Name has a significant relationship with perceived product quality. These findings are in line with the limited previous findings of (Mohammad et al., 2011; Othman et al., 2016). On the other hand, nutritional label was found to have stout nexus with perceived product quality, accepting the second hypothesis of the study. The results confirmed the findings of (Huang and $\mathrm{Lu}, 2016$; Appelhans et al., 2017).

\section{LIMITATTIONS OF THE STUDY}

This particular study has adopted packaged food sector for study. The cities of Islamabad and Rawalpindi were selected to collect data and the sample of 480 consumers was used. The future researchers can expand the number of cities to more cities of Pakistan as well as similar kind of study could be generalized to other products other than packaged foods.

\section{IMPLICATIONS}

From the standpoint of practitioners, this study provides a significant contribution in the form of understanding the mindset of consumers in a shopping situation. It may also assist the marketers to devise the marketing strategies to create favorable product perceptions and long-term relations with the consumers.

\section{References}

1) Appelhans, B. M., French, S. A., Tangney, C. C., Powell, L. M., \& Wang, Y. (2017). To what extent do food purchases reflect shoppers' diet quality and nutrient intake?. International Journal of Behavioral Nutrition and Physical Activity, 14(1), 46.

2) Akhtar, N., Siddiqi, U. I., Ashraf, A., \& Latif, M. (2016). Impact of a Brand Equity on Consumer Purchase Decision in L'Oreal Skincare Products. International Review of Management and Business Research, 5(3), 808.

3) Bailey, R. L. (2017). Influencing Eating Choices: Biological Food Cues in Advertising and Packaging Alter Trajectories of Decision Making 
and Behavior. Health communication, 32(10), 1183-1191.

4) Baron, R. M., \& Kenny, D. A. (1986). The moderator-mediator variable distinction in social psychological research: Conceptual, strategic, and statistical considerations. Journal of personality and social psychology, 51(6), 1173.

5) Bialkova, S., Sasse, L., \& Fenko, A. (2016). The role of nutrition labels and advertising claims in altering consumers' evaluation and choice. Appetite, 96, 38-46.

6) Borzooei, M., \& Asgari, M. (2013). Establishing a global halal hub: In-depth interviews. International Journal of Academic Research in Business and Social Sciences, 3(10), 169.

7) Campos, S., Doxey, J., \& Hammond, D. (2011). Nutrition labels on pre-packaged foods: a systematic review. Public health nutrition, 14(8), 1496-1506.

8) Chadwick, S., \& Holt, M. (2015). Utlising Latent Brand Equity as a Foundation for Building Global Sports Brands. In Proceedings of the 2007 Academy of Marketing Science (AMS) Annual Conference (pp. 90-98). Springer International Publishing.

9) Chandon, P., \& Wansink, B. (2007). The biasing health halos of fast-food restaurant health claims: lower calorie estimates and higher side-dish consumption intentions. Journal of Consumer Research, 34(3), 301-314.

10) Chaya, C., Pacoud, J., Ng, M. L., Fenton, A., \& Hort, J. (2015). Measuring the emotional response to beer and the relative impact of sensory and packaging cues. Journal of the American Society of Brewing Chemists, 73(1), 49-60.

11) Chin, W. W., Marcolin, B. L., \& Newsted, P. R. (2003). A partial least squares latent variable modeling approach for measuring interaction effects: Results from a Monte Carlo simulation study and an electronic-mail emotion/adoption study. Information systems research, 14(2), 189217.

12) Darkwa, S. (2014). Knowledge of nutrition facts on food labels and their impact on food choices on consumers in Koforidua, Ghana: a case study. South African Journal of Clinical Nutrition, 27(1), 13-17.
13) Drichoutis, A. C., Lazaridis, P., \& Nayga Jr, R. M. (2006). Consumers' use of nutritional labels: a review of research studies and issues. Academy of marketing science review, 2006, 1.

14) Fornell, C., \& Larcker, D. F. (1981). Structural equation models with unobservable variables and measurement error: Algebra and statistics. Journal of marketing research, 382-388.

15) Garber Jr, L. L., Hyatt, E. M., \& Starr Jr, R. G. (2000). The effects of food color on perceived flavor. Journal of Marketing Theory and Practice, 8(4), 59-72.

16) Glanz, K., Basil, M., Maibach, E., Goldberg, J., \& Snyder, D. A. N. (1998). Why Americans eat what they do: taste, nutrition, cost, convenience, and weight control concerns as influences on food consumption. Journal of the American Dietetic Association, 98(10), 1118-1126.

17) Grunert, K. G., \& Aachmann, K. (2016). Consumer reactions to the use of EU quality labels on food products: A review of the literature. Food Control, 59, 178-187.

18) Grunert, K. G., \& Wills, J. M. (2007). A review of European research on consumer response to nutrition information on food labels. Journal of public health, 15(5), 385-399.

19) Hair, J. F., Ringle, C. M., \& Sarstedt, M. (2011). PLS-SEM: Indeed a silver bullet. Journal of Marketing theory and Practice, 19(2), 139-152.

20) Hieke, S., \& Taylor, C. R. (2012). A critical review of the literature on nutritional labeling. Journal of Consumer Affairs, 46(1), 120156.

21) Huang, L., \& Lu, J. (2016). The impact of package color and the nutrition content labels on the perception of food healthiness and purchase intention. Journal of food products marketing, 22(2), 191-218.

22) Ismail, W. R. B. W., Othman, M., Rahman, R. A., Kamarulzaman, N. H., \& Rahman, S. A. (2016). Halal Malaysia Logo or Brand: The Hidden Gap. Procedia Economics and Finance, 37, 254261.

23) Khan, S., \& Nasr, M. (2010). Women as a consumer force and decision maker in Pakistani household. Research for Rethinking, Proceedings 12th International Business Research Conference 
International Journal of Trend in Scientific Research and Development (IJTSRD) ISSN: 2456-6470

of the World Business Institute Australia, Dubai, United Arab Emirates.

24) Lee, H. M., Lee, C. C., \& Wu, C. C. (2011). Brand image strategy affects brand equity after M\&A. European Journal of Marketing, 45(7/8), 1091-1111.

25) Lewis, K. E., Grebitus, C., \& Nayga, R. M. (2016). The impact of brand and attention on consumers' willingness to pay: Evidence from an eye tracking experiment. Canadian Journal of Agricultural Economics/Revue canadienne d'agroeconomie, 64(4), 753-777.

26) Lindley, P., \& Walker, S. N. (1993). Theoretical and methodological differentiation of moderation and mediation. Nursing Research, 42(5), 276-279.

27) Mohd Suki, N., \& Abang Salleh, A. S. (2016). Does Halal image strengthen consumer intention to patronize Halal stores? Some insights from Malaysia. Journal of Islamic Marketing, 7(1), 120-132.

28) Muth, M. K., Zhen, C., Taylor, J., Cates, S., Kosa, K., Zorn, D., \& Choiniere, C. (2013). The value to consumers of health labeling statements on breakfast foods and cereals. Journal of food products marketing, 19(4), 279-298.

29) Othman, B., Shaarani, S. M., \& Bahron, A. (2016). The Potential of ASEAN in Halal Certification Implementation: A Review. Pertanika Journal of Social Sciences \& Humanities, 24(1).

30) Peters-Texeira, A., \& Badrie, N. (2005). Consumers' perception of food packaging in Trinidad, West Indies and its related impact on food choices. International Journal of Consumer Studies, 29(6), 508-514.

31) Randhawa, P., Kirca, A. H., Talay, M. B., \& Akdeniz, M. B. (2017). Interactive Effects of Product and Brand Portfolios on Firm Value. In Creating Marketing Magic and Innovative Future Marketing Trends (pp. 95-98). Springer, Cham.

32) Riaz, M. N., \& Chaudry, M. M. (2004). The value of Halal food production-Mian N. Riaz and Muhammad M. Chaudry define what Halal and kosher foods are, describe why they are not the same thing, and what is required of processors and. Inform-International News on Fats Oils and Related Materials, 15(11), 698-701.

33) Rothschild, A. W., Romano, J. P., \& Bozogian, R. A. (1998). U.S. Patent No. 5,802,015. Washington, DC: U.S. Patent and Trademark Office.

34) Sekaran, U. (2003). Research method for business: a skill building approach (4th ed.). Singapore: John Wiley \& Sons.

35) Sekaran, U., \& Bougie, R. (2010). Research methods for business: A skill building approach. Wiley.

36) Sharma, K., \& Garg, S. (2016). An Investigation into Consumer Search and Evaluation Behaviour: Effect of Brand Name and Price Perceptions. Vision, 20(1), 24-36.

37) Talati, Z., Pettigrew, S., Kelly, B., Ball, K., Dixon, H., \& Shilton, T. (2016). Consumers' responses to front-of-pack labels that vary by interpretive content. Appetite, 101, 205-213.

38) Teisl, M. F., \& Levy, A. S. (1997). Does nutrition labeling lead to healthier eating?. Journal of Food Distribution Research, 28, 18-27.

39) Trifts, V., Huang, L., \& Häubl, G. (2013). Price versus nice? How unfavorable price comparisons help retain customers. Journal of Marketing Theory and Practice, 21(2), 163-178.

40) Uma, S., \& Roger, B. (2003). Research methods for business: A skill building approach. book.

41) Underwood, R. L. (2003). The communicative power of product packaging: creating brand identity via lived and mediated experience. Journal of Marketing Theory and Practice, 11(1), 62-76.

42) Van den Wijngaart, A. W. (2002). Nutrition labelling: purpose, scientific issues and challenges. Asia Pacific journal of clinical nutrition, 11(2).

43) Verhoef, P. C., Nijssen, E. J., \& Sloot, L. M. (2002). Strategic reactions of national brand manufacturers towards private labels: An empirical study in the Netherlands. European Journal of Marketing, 36(11/12), 1309-1326.

44) Vinzi, V. E., Chin, W. W., Henseler, J., \& Wang, H. (Eds.). (2010). Handbook of partial least 
International Journal of Trend in Scientific Research and Development (IJTSRD) ISSN: 2456-6470

squares: Concepts, methods and applications. Springer Science \& Business Media.

45) Winkielman, P., McIntosh, D. N., \& Oberman, L. (2009). Embodied and disembodied emotion processing: Learning from and about typical and autistic individuals. Emotion Review, 1(2), 178190.

46) Wills, J. M., Schmidt, D. B., Pillo-Blocka, F., \& Cairns, G. (2009). Exploring global consumer attitudes toward nutrition information on food labels. Nutrition Reviews, 67(suppl_1), S102S106.

47) Wilson, J. A., \& Liu, J. (2010). Shaping the halal into a brand?. Journal of Islamic Marketing, 1(2), 107-123.

48) Zeb, H., Rashid, K., \& Javeed, M. B. (2011). Influence of Brands on Female Consumer's Buying Behavior in Pakistan. International Journal of Trade, Economics and Finance, 2(3), 225.

Table 2: Descriptive Statistics

\begin{tabular}{|c|c|c|c|c|c|}
\hline Construct & $\mathrm{N}$ & Minimum & Maximum & Mean & Standard Deviation \\
\hline Nutritional Label & 478 & 1 & 5 & 3.7436 & 0.66230 \\
\hline Brand Name & 478 & 1 & 5 & 4.103 & 0.5746 \\
\hline Perceived Product Quality & 478 & 1 & 5 & 4.0753 & 0.67987 \\
\hline
\end{tabular}

\section{Table No: 3 Reliability Coefficient}

\begin{tabular}{|c|c|c|c|c|c|}
\hline Serial No & Construct & $\begin{array}{c}\text { Cronbach } \\
\text { Alpha }\end{array}$ & $\begin{array}{l}\text { No .of } \\
\text { Items }\end{array}$ & Items & $\begin{array}{c}\text { Alpha if item is } \\
\text { deleted }\end{array}$ \\
\hline 1. & Nutritional label & $\begin{array}{l}\text { To.707 } \\
\text { search } \\
\text { velopm }\end{array}$ & $\begin{array}{l}\text { te } \\
\text { and }\end{array}$ & $\begin{array}{l}\text { NL1 } \\
\text { NL2 } \\
\text { NL3 } \\
\text { NL4 } \\
\text { NL5 } \\
\text { NL6 } \\
\text { NL7 }\end{array}$ & $\begin{array}{l}0.631 \\
0.663 \\
0.690 \\
0.733 \\
0.650 \\
0.668 \\
0.672\end{array}$ \\
\hline 2. & Brand Name & 0.836 & & $\begin{array}{l}\text { BN1 } \\
\text { BN2 } \\
\text { BN3 } \\
\text { BN4 } \\
\text { BN5 } \\
\text { BN6 } \\
\text { BN7 } \\
\text { BN8 } \\
\text { BN9 }\end{array}$ & $\begin{array}{l}0.820 \\
0.825 \\
0.821 \\
0.811 \\
0.821 \\
0.823 \\
0.812 \\
0.810 \\
0.828 \\
\end{array}$ \\
\hline 3. & Perceived quality & 0.851 & 9 & $\begin{array}{l}\text { PQ1 } \\
\text { PQ2 } \\
\text { PQ3 } \\
\text { PQ4 } \\
\text { PQ5 } \\
\text { PQ6 } \\
\text { PQ7 } \\
\text { PQ8 } \\
\text { PQ9 }\end{array}$ & $\begin{array}{l}0.874 \\
0.872 \\
0.867 \\
0.870 \\
0.862 \\
0.863 \\
0.860 \\
0.869 \\
0.875 \\
\end{array}$ \\
\hline
\end{tabular}

